\title{
6 Trik Manajemen Sumber Daya Manusia yang Profesional
}

\section{Zulfiyatus Saufillah}

\author{
Universitas Nahdlatul Ulama Sidoarjo \\ zulfiyatus@tutanota.com
}

\begin{abstract}
Manajemen Sumber Daya Manusia (SDM) atau Human resource (HR) yang esensial dan fundamental bagi sebuah perusahaan dengan staf atau karyawan. Manajemen Sumber Daya Manusia adalah tanggung jawab untuk produktivitas dan hubungan konstruktif organisasi dengan karyawannya (Purnomo, Putri, \& Rosyidah, 2017). Manajemen Sumber Daya Manusia digunakan sebagai penunjang untuk meningkatkan perekonomian (Asitah et al., 2018).
\end{abstract}

Mengelola organisasi membutuhkan manajemen SDM (Maula et al., 2017). Jika kita hanya perusahaan rintisan, kita mungkin mengelola manajemen SDM secara mandiri sendiri. Namun, sebagian besar suatu perusahaan besar memiliki seluruh departemen yang ditujukan guna merekrut, 
mengelola dan mempertahankan staf yang ada dan tepat. Ini adalah pekerjaan yang membutuhkan komitmen, dedikasi, profesionalisme, dan organisasi. Seperti halnya sektor bisnis apa pun, mengelola manajemen SDM memiliki tantangan dan dinamika, tetapi secara umum masalah manajemen SDM dapat diselesaikan dengan beberapa trik dan tips berikut ini.

\section{Terbuka untuk Mendengarkan}

Ini kembali ke memiliki kebijakan komunikasi terbuka - bahkan jika Anda tidak setuju dengan pendapat seseorang, Anda tidak harus mencegah mereka untuk menyuarakan pandangan mereka. Ada pengecualian (seperti diskriminasi), tetapi terkadang kebijakan perlu diperbarui atau langkah-langkah yang diambil untuk memperbaiki keadaan saat ini (Mulholland, 2017).

\section{Matematika}

Anda dijanjikan bahwa Anda tidak perlu melakukan matematika di bidang SDM; itu sebabnya Anda memilihnya daripada akuntansi. Maaf! Meskipun Anda tidak perlu melakukan matematika sebanyak yang Anda lakukan dalam akuntansi, banyak pekerjaan 
kepatuhan membutuhkan pemahaman yang kuat tentang matematika dan statistik. Anda akan memerlukan keterampilan ini untuk menafsirkan laporan tindakan afirmatif, membuat laporan omset, menentukan gaji, dan berbicara secara cerdas dengan orang-orang bisnis yang sangat fokus pada angka. Pengukuran untuk mengkonfirmasi kelayakan praktik dan program SDM lebih penting dari sebelumnya (Lucas, 2019).

\section{Pekerjakan Orang Lebih Baik daripada Anda untuk Menciptakan Perusahaan Profesional}

Mempekerjakan bukanlah segalanya tentang menemukan orang yang paling cocok dengan persyaratan pekerjaan Anda. Mereka penting, ya, tetapi harus berfungsi sebagai lebih banyak bar untuk masuk daripada apa pun yang signifikan untuk keputusan perekrutan. Alih-alih, Anda perlu mencoba dan menemukan orang-orang yang sama-sama lebih baik daripada yang Anda butuhkan dan yang cocok dengan anggota tim Anda yang lain. Begini; jika Anda mempekerjakan seseorang yang hampir tidak memenuhi persyaratan minimum Anda, manfaat di luar pengaturan inti "pembayaran vs pekerjaan 
selesai" sepenuhnya menguntungkan karyawan. Mereka akan mendapatkan pengalaman ekstra, perusahaan lain di resume mereka, dan mengasah keterampilan mereka melalui pekerjaan. Sebagai imbalannya, Anda mendapat sedikit tambahan selain (bisa dibilang) kesetiaan karyawan itu. Sebaliknya, jika Anda mempekerjakan seseorang yang lebih baik daripada Anda (atau setidaknya seseorang yang sangat berpengalaman) maka manfaat itu akan dibatalkan. Tiba-tiba, tim Anda adalah orang-orang yang belajar dari pengalaman dan pengetahuan karyawan baru di bidangnya (Mulholland, 2017).

\section{Mengelola Orang}

Sebagai manajer SDM, Anda mungkin tidak memiliki laporan langsung, tetapi Anda perlu memahami cara mengelola orang. Anda akan melatih dan bertindak sebagai orang kepercayaan bagi para manajer. Anda harus membantu mereka mengelola orang-orang mereka. Dalam beberapa peran SDM, Anda akan bertindak sebagai manajer de facto bagi banyak orang, bahkan jika Anda bukan orang yang menulis penilaian kinerja tahunan mereka (Lucas, 2019). 


\section{Pahami orang dan SDM-mu}

Pertama dan terutama, untuk mulai dengan, memahami orang-orang Anda, tahu bahwa peran SDM dimulai dengan empati. Biasakan diri dengan karyawan Anda kehidupan pribadi, tonggak sejarah dan peringatan hari kerja, peran, kaliber, kekuatan, kelemahan, kenyamanan dan ketidaknyamanan, dll. Nilai keanekaragaman dan belajar untuk mengembangkan keseimbangan di dalamnya. Ini adalah investasi yang perlu Anda lakukan sejak hari pertama karena akan membantu Anda dalam jangka panjang ketika datang untuk menciptakan budaya yang tepat, meningkatkan keterlibatan dan produktivitas karyawan, dan mencapai tujuan keseluruhan (Sondhi, 2018).

\section{Informasi Mudah Diakses oleh yang Membutuhkannya}

Berbagi informasi sangat penting. Ini adalah area di mana banyak perusahaan besar berjuang: Bagaimana Anda melacak siapa yang tahu apa, jadi Anda tahu ke mana harus pergi dengan pertanyaan Anda ?. Ada dua alasan mengapa berbagi informasi sangat penting. Pertama, komunikasi terbuka tentang strategi, keuangan, dan operasi menciptakan 
budaya di mana orang merasa mereka dipercaya. Ini benar-benar melibatkan karyawan dalam bisnis. Sebagai efek tambahan, itu mengecilkan kata-kata dan obrolan informal yang negatif. Kedua, jika Anda ingin orang-orang Anda membagikan ide-ide mereka, mereka perlu memiliki pemahaman yang mendalam tentang apa yang sedang terjadi dalam bisnis. Diinformasikan tentang bisnis juga merupakan sesuatu yang sering disebut karyawan sebagai sesuatu yang mereka anggap penting dalam survei sikap, serta memiliki kesempatan untuk berkontribusi dan memengaruhi keputusan yang mempengaruhi kehidupan kerja mereka (Vulpen, 2018).

\section{References}

Alexander, M. (2019). 5 HR Management Tips to Improve Team Performance. Retrieved June 2, 2019, from https://www.techrepublic.com/article/5-hrmanagement-tips-to-improve-teamperformance/ 
Asitah, N., Maula, I., Munjidah, A., Nahdiyah,

K., Yuniarti, D., Sholichah, S. A.,

Purnomo, A., Rosyidah, E., Anam, F.,

Achmadi, A.K., \& Fahmi, M. (2018, May

25). Urgensi Aktualisasi Manajemen

Sumber Daya Manusia untuk Resurgensi

Perekonomian di Sidoarjo.

http://doi.org/10.17605/OSF.IO/TG79P

Lucas, S. (2019). 10 Skills Every HR Manager

Needs to Succeed. Retrieved May 28, 2019, from

https://www.thebalancecareers.com/skills-

hr-managers-need-to-succeed-4138124

Maula, I., Mufidah, F.I., Rosyidah, E., \&

Purnomo, A. (2017). SD Antawirya Islamic Javanese School Mother is Culture. In Wirausaha Pendidikan Indonesia (Jilid 1). Sidoarjo: Unusida Press.

Mulholland, B. (2017). 12 HR Management Tips to Run an Effective Business (and Prevent Total Chaos). Retrieved June 1, 2019, from https://www.process.st/hrmanagement-tips/

Purnomo, A., Putri, R. A., \& Rosyidah, E. (2017). Kamus Manajemen Sumber Daya Manusia. Sidoarjo: UNUSIDA Press. 
Sondhi, P. (2018). Be an Outstanding HR Professional with these 7 Tips. Retrieved May 27, 2019, from https://www.entrepreneur.com/article/3128 94

Vulpen, E. van. (2018). 7 Human Resource Best Practices (A mini-guide to HRM). Retrieved June 4, 2019, from https://www.digitalhrtech.com/humanresource-best-practices/ 